ELORE (ISSN 1456-3010), vol. $14-2 / 2007$.

Julkaisija: Suomen Kansantietouden Tutkijain Seura ry.

[http://www.elore.fi/arkisto/2_07/tuu2_07.pdf]

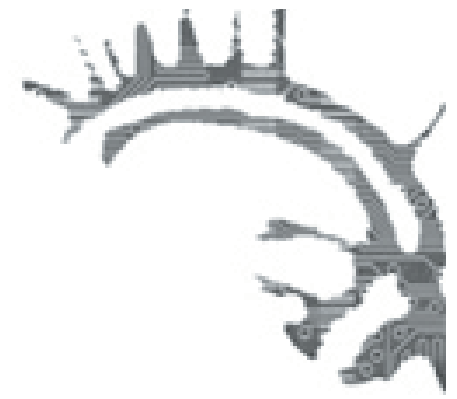

\title{
Ajankohtaista: \\ Tilattuja tarinoita. Etnografinen tUtKimus \\ POHJOISKARJALAISESTA TIETOYHTEISKUNNASTA
}

\author{
Lectio praecursoria 31.8.2007 Joensuun yliopistossa
}

\section{$\underline{\text { Sari Tuuva-Hongisto }}$}

Joulukuussa 2000 Nurmeksen Bomballa järjestettiin tietoyhteiskuntaseminaari, jossa esiteltiin tulevaisuuden tietoyhteiskuntahaasteita. Seminaari oli järjestetty, sillä maailman johtava tietoyhteiskuntatutkija Manuel Castells oli vierailulla Suomessa ja tutustumassa syrjäseudun tietoyhteiskuntahankkeeseen, Oppiva Ylä-Karjalaan. Seminaarissa Oppiva Ylä-Karjala -hanketta esitteli projektin päällikkö Ilpo Koskikallio. Koskikallio kertoi hankkeen menestyksestä ja hankkeessa rakennetun kansalaisverkon vilkkaasta kansalaiskeskustelusta sekä ennakko-odotuksia ylittäneistä käyttäjämääristä. Myös Manuel Castells piti puheenvuoron, jossa hän johtavana tietoyhteiskuntateoreettikkona esitteli informaatioajan haasteita.

Seminaariin tarvittiin myös hankkeisiin osallistuneen puheenvuoro ja kokemuksen ääni. Esiin astui aiemmin samana syksynä haastattelemani Riikka, joka kertoi Oppiva Ylä-Karjalasta oman tarinansa. Hän kertoi, kuinka oli oppinut hankkeessa käyttämään tietotekniikkaa ja sen mahdollisuuksia, oli saanut työllistyä projektiin ja sai olla viemässä "tietotekniikan ilosanomaa kylille". Seminaari-illassa vallitsi harras tunnelma. Kaikki tuntuivat olevan yhtä mieltä siitä, että tietotekniikassa oli seudun tulevaisuus ja pelastus. Hanketta sekä tietoyhteiskunnan kehittämistä ylistettiin ja kiiteltiin.

Seminaarin tunnelma ei ollut poikkeuksellinen 2000-luvun vaihteessa. Tietoyhteiskunta oli kasvavan kiinnostuksen kohteena. Sitä kehitettiin, rahoitettiin ja myös tutkittiin. Tietotekniikka oli vahvasti tulevaisuuden ala ja tietoyhteiskuntakehittämiseen panostettiin.

Suomessa toteutettiin vuosituhannen vaihteessa satoja tietoyhteiskunnan kehittämishankkeita, sillä vallalla oli teknologian ja tietoyhteiskunnan nousukausi. Kehitystä vauhdittivat Euroopan unionin tietoyhteiskuntaohjelmat sekä rahoitus, 


\section{TILATTUJA TARINOITA}

joka mahdollisti suurimman osan tietoyhteiskunnan kehittämishankkeiden toteutuksesta.

Pohjois-Karjalassa tietoyhteiskunnan kehittäminen aloitettiin 1990-luvun puolessa välin. Tietoyhteiskunnan tekemistä ohjasi Pohjois-Karjalan maakuntaliitto, ja sitä toteutettiin lukuisin kehittämishankkein. Yksi keskeisimmistä pohjoiskarjalaisista tietoyhteiskuntahankkeista oli Oppiva Ylä-Karjala, paikallinen tietoverkkohanke, josta otettiin mallia myös muualle Suomeen. Hankkeesta tuli "menestystarina".

Olen seurannut tätä menestystarinaa sen alusta lähtien. Olen syksystä 1998 lähtien seurannut erilaisissa Suomen Akatemian sekä Kauppa- ja teollisuusministeriön rahoittamissa hankkeissa pohjoiskarjalaista tietoyhteiskuntaa. Kulttuurintutkijana olen tehnyt tutkimusta etnografisin menetelmin ja oma tutkimukseni on aina limittynyt ja lomittunut tutkimushankkeiden näkökulmiin.

Tutkimushankkeiden kuluessa on koottu seitsemän vuoden ajalta ainutlaatuinen haastatteluaineisto pohjoiskarjalaisen tietoyhteiskunnan rakentumisesta. Haastateltavat olivat sekä tietoyhteiskuntahankkeiden osallistujia että suunnittelijoita ja toteuttajia. Suurta osaa hankkeisiin osallistuneista on seurattu useiden haastattelujen sarjoina, joissa tietotekniikan ja tietoyhteiskunnan tulkinnat muotoutuivat vähitellen, prosessinomaisesti. Haastatteluja tehtiin erityisesti Oppiva Ylä-Karjala sekä Kantti (Kansalainen, sukupuoli ja tietoyhteiskunta) -hankkeista. Oppiva Ylä-Karjala -hankkeessa yläkarjalaiset työttömät opettelivat tietotekniikan käyttötaitoja ja rakensivat alueelle paikallisen kansalaisverkon alueen asukkaiden käyttöön. Toinen tutkimuksessa seurattu hanke oli Kantti, naisille suunnattu tietotekniikkakurssi, jonka käyttäjä- ja kansalaislähtöisen opetuksen tavoitteena oli sujuvoittaa naisten arkea. Hankkeita seurattiin paitsi haastattelemalla, myös osallistumalla erilaisiin kokouksiin ja seminaareihin, keräämällä asiakirjoja, esitteitä ja hankkeiden tuottamia materiaaleja sekä seuraamalla niin paikallisia kuin kansallisiakin tietoyhteiskuntastrategioita ja julkista keskustelua.

Bomban seminaari-ilta sai minut ensimmäisen kerran miettimään tarinoiden erilaisia tilauksia. Riikka oli haastatteluissani kertonut aivan erilaisen tarinan suhteestaan tietotekniikkaan. Riikka oli kertonut siitä, kuinka hän oli jo lapsesta asti ollut kiinnostunut kaikenlaisesta teknisestä ja oli tutustunut tietotekniikkaan pelaamisen kautta. Hän oli myös opiskellut tietotekniikkaa ennen projektiin osallistumista. Haastatteluissa Riikka kertoi tietotekniikan jo liiaksikin hallitsevan jokapäiväistä elämää. Kertoiko Riikka minulle vain sen tarinan, jonka halusinkin kuulla, ja jonka hän oletti minun haluavan kysymysteni ja tutkimukseni pohjalta? Kertoiko Riikka Castellsille seminaarissa sen tarinan, jonka Castells halusi kuulla? Oliko kyse vain erilaisista tilauksista, erilaisista tarinoista ja erilaisista konteksteista, sitoumuksista ja tarkoituksista?

Pohjoiskarjalaisen tietoyhteiskunnan etnografinen tutkimukseni avautuu tilattuina tarinoina. Kysymys tarinoiden tilauksesta asettuu sekä tiedon tuottamisen tapaan, aineistonmuodostukseen sekä siitä tehtävien tulkintojen problematiikaksi. Tutkimuksessa kysyn: Millaisissa tarkoituksissa, sitoumuksissa ja konteksteissa pohjoiskarjalaisia tietoyhteiskuntatulkintoja tuotettiin? Tilatut tarinat asettavat lisäksi kysymyksen työn kontekstin hahmottamiselle: Millainen merkitys pohjoiskarjalaisilla tietoyhteiskunnan kehittämisen tarinoilla oli osana kansallista teknologian kehittämisprojektia?

Nostan esiin myös kysymykset arjesta, sukupuolesta sekä paikallisuudesta. 


\section{SARI TUUVA-HONGiSTO}

Arjen ja tietotekniikan artikulaatio muotoutuu tutkimukseni kehyksessä muotoon: Miten arki ja tietotekniikka nivoutuvat yhteen? Teknologian ja sukupuolen yhteydessä tarkastelen kysymystä: Miten teknologian ja sukupuolen suhde on koettu ja kuinka sitä on tietoyhteiskuntahankkeissa tuotettu? Paikallisuuden ja tietoyhteiskunnan suhteesta kysyn: Millaisia ovat paikallisuuden tulkinnat osana tietoyhteiskunnan rakentamista?

Kulttuurintutkimus muodostaa työni keskeisen teoreettisen taustan ja nostaa esiin tutkimukseni kysymysten ja näkökulmien konstruoituvan luonteen. Kulttuurintutkimuksen keskeinen piirre onkin ymmärtää kulttuuria elettynä konstruktiona sekä ymmärtää jokapäiväisen elämän materiaalisia, sosiaalisia ja symbolisia käytäntöjä (Gray 2003, 1). Näkökulmassani painottuvat teknologian etnografinen kulttuurintutkimus ja tulkinnallisuus. Tutkimuksen metodologinen ote paikantuu etnografiaan, jolla tarkoitan sekä dialogia tutkittavien kanssa että neuvotteluja tehtävistä tulkinnoista ja merkityksistä. Etnografisen tutkimuksen kokemuksellisuus ja tulkinnallisuus, sekä tulkintojen kiinnittyminen laajempiin yhteiskunnallisiin konteksteihin ovat työssäni keskeisiä.

Tutkimukseni edustaa teknologian yhteiskunnallista ja kulttuurista tutkimusta, joka pohjaa teknologian ymmärrykseen sekä artefakteina, sosiaalisina käytäntöinä että tietämyksenä (McKenzie \& Wajcman 1985). Teknologia siis viittaa sekä itse välineisiin että ennen kaikkea ihmisten toimintaan, tietämykseen, tulkintoihin ja merkityksiin. Teknologian kulttuurinen tutkimus tutkiikin teknologiaan liittyviä tulkintoja, merkityksiä, käyttötapoja ja ymmärryksiä (Mackay 1997). Työssäni tekstuaalisuus yhdistyy etnografiaan: tulkitsen teknologiaa kulttuurisena tekstinä.

Tarkastelen tietoyhteiskunnan kulttuurisia tulkintoja tilattuina tarinoina. Tilattujen tarinoiden käsitteen avulla hahmotan etnografisen tutkimuksen refleksiivistä lähestymistapaa. Tilatut tarinat avaavat myös tutkimuksen kontekstia, tietoyhteiskunnan kehittämistä laajamittaisena kansallisena projektina, jossa tietotekniikka valjastettiin suomalaisen yhteiskunnan ja identiteetin rakentamiseen.

Tilatuilla tarinoilla pyrin kiinnittämään huomion tiedon paikantuneisuuteen sekä tiedon tuottamisen sitoumuksiin (Haraway 1991). Etnografinen tietäminen on tietämistä jostakin näkökulmasta: ei ole tietämystä ilman jotakuta, joka tietää, tietyllä tavalla (Hastrup 2004). Vaikka tulkintojen voi katsoa olevan avoimia, moniäänisiä ja neuvottelunvaraisia, niitä kuitenkin aina tuotetaan jotakin tarkoitusta varten. Tutkimuksella sekä tulkinnoilla on omat sitoumuksensa ja rajoituksensa. Refleksiivisyys onkin tilattujen tarinoiden läpäisevä ajatus: tilaus muistuttaa sekä tutkimuksen erilaisista sitoumuksista että tutkimuksessa tuotetun ja konstruoidun tiedon tilatusta luonteesta.

Teen tietoyhteiskunnasta kulttuurisia tulkintoja ja tuon esiin sen konstruktiivisen luonteen: miten tietoyhteiskunnasta on puhuttu ja miten sitä on kansalaisille tuotettu. Lähestyn tietoyhteiskuntaa poliittisena konstruktiona, kehittämispuheena, kehittämishankkeina sekä tutkimuksessani esiintyvinä tulkintoina. Tietoyhteiskunnan tarkastelu rajautuu 2000-luvun vaihteen kiihkeän keskustelun kauteen, jolloin tietoyhteiskuntaa kehitettiin sekä valtakunnallisesti että paikallisesti erilaisin strategioin ja kehittämishankkein. Lähestyn tietoyhteiskuntaa tämän kehittämispuheen kautta suurena diskurssina sekä suomalaisten uutena identiteettikertomuksena, tapana ku- 


\section{TILATTUJA TARINOITA}

vata Suomi tietotekniikan hyödyntämisen kärkimaana ja edelläkävijänä. Tuon esiin tietoyhteiskunnan luonteen kansallisena projektina, johon meidän kaikkien oletettiin osallistuvan. Yhdistän työssäni pohjoiskarjalaisen tietoyhteiskunnan tekemisen osaksi kansallista tietoyhteiskunnan rakentamista.

Prosessinomaisuus sekä pitkäkestoinen seuranta ovat jäsentäneet työtäni. Etnografinen tutkimukseni on seurannut ainutlaatuista ajanjaksoa, jolloin tietoyhteiskuntaa kehitettiin Suomessa. Tutkimus käynnistyi samaan aikaan kuin tietoyhteiskuntaprojektit alkoivat Pohjois-Karjalassa: seurantaluonteisuus ja samanaikaisuus ovat muovanneet tutkimuksen suuntia ja kysymyksenasetteluja. Myös tutkimusprojekteissa työskentely ja tutkimuksen tekeminen osana laajoja tutkimushankkeita tuo työhön omat painotuksensa. Artikkeleina julkaistut osatutkimukset toteuttavat työn prosessija seurantaluonnetta ja tutkimuskohteen konstruoituvaa olemusta.

Väitöskirjani rakentuu työn kokoavasta johdannosta sekä viidestä vuosina 2000-2004 julkaistusta artikkelista. Työn ensimmäinen artikkeli "Tilattuja tarinoita tietotekniikan arjesta" (2003) tuo esiin tilattujen tarinoiden idean sekä pohtii tietotekniikan arkipäiväistymisen prosesseja. Työn toinen artikkeli "Sinuja koneen kanssa - tulkintoja tietotekniikasta"(2000) tarkastelee kahden tietoyhteiskuntahankkeeseen osallistuneen naisen kokemuksia ja tulkintoja tietotekniikasta ja sukupuolesta. Kolmas artikkeli "Interpretations of information society in North Karelia" (2003) jatkaa arkipäiväistymisen teemaa sekä laajentaa sukupuolen ja teknologian suhteen tarkastelua siihen, kuinka hankkeet tuottivat teknologian sukupuolittumista. Neljäs artikkeli "'Sä et oo ennää syrjässä’ - paikasta ja paikallisuudesta Ylä-Karjalassa” (2001) tarkastelee paikallisuuden ja paikan tulkintoja tietoyhteiskunnassa. Työn viimeinen, viides artikkeli "Negotiated stories of the information society" (2004) jatkaa tilattujen tarinoiden käsittelyä metodologisena lähestymistapana.

Väitöskirjassani tietoyhteiskunnan tulkinnat paikantuvat arjen, sukupuolen ja paikallisuuden näkökulmiin. Työssä on tarkasteltu sitä, miten nämä näkökulmat yhdistyvät tietotekniikkaan ja millaisia tulkintoja näistä artikulaatioista syntyy.

Tutkimuksessani arki ja tietotekniikka nivoutuivat yhteen tietoyhteiskunnan kehittämisen kontekstissa. Arjella on tietoyhteiskuntakehittämisen sekä arjen ja tietotekniikan yhdistelmänä oma erityinen merkityksensä yleisyytenä ja useutena. Tietoyhteiskunnan arkistuminen tarkoittaa tietoyhteiskunnan läpäisevyyttä. Arki näyttäytyy tietotekniikan omaksumisen loppupisteenä, johon tietotekniikka asettuu ja vakiintuu. Arki sitoo tietoyhteiskunnan myös tavallisuuteen, kansanomaisuuteen ja elettyihin kokemuksiin. Arjen ja tietotekniikan korostamisella on haettu esimerkiksi strategioissa ja tietoyhteiskuntakeskusteluissa läpäisevyyttä ja yleisyyttä. Arjen korostaminen on myös siirtänyt lähestymistapaa pois teknologiavetoisesta näkökulmasta. Pukemalla yleisyys arkiseksi tekee arjesta omaksumisen ja leviämisen päätepisteen, mutta luo kuvan siitä, että omaksujalla on aktiivinen ja toiminnallinen rooli. Tietotekniikan arkinen hyödyntäminen tekee arjesta sujuvampaa.

Pohjoiskarjalaisessa tietoyhteiskunnan kehittämisessä sukupuoleen kiinnitettiin huomiota, ja naisten suhdetta tietotekniikkaan tuettiin ja pyrittiin määrittelemään uudelleen. Tulkinnat sukupuolen ja teknologian suhteesta kuitenkin muuntuivat kehittämisen konteksteissa keskusteluihin tasa-arvosta. Tietoyhteiskunnassa tasa-arvo 


\section{SARI TUUVA-HONGiSTO}

perustuu ajatukseen samanlaisista mahdollisuuksista, jossa erot näyttäytyvät omina mieltymyksinä ja valintoina. Teknologian tai tietotekniikan sukupuolittunut luonne jäi näin ollen tasa-arvoideaalin katveeseen, joka toimi eroja pikemminkin vahvistaen kuin purkaen. Tulkinnat sukupuolen ja teknologian suhteesta noudattelivat siis käsitystä samanlaisista mahdollisuuksista: tasa-arvo liittyy itsestään selvänä suomalaisen yhteiskunnan järjestykseen. Tasa-arvoisessa tietoyhteiskunnan kehittämisessä oli tärkeä saada kaikki - sukupuoleen, ikään ja asuinpaikkaan katsomatta - mukaan yhteisiin tietoyhteiskuntatalkoisiin.

Ylä-Karjalan kansalaisverkko perustui paikallisuuteen. Paikallisuuden korostaminen vuosituhannen lopulla muodosti eräänlaisen vastakertomuksen paikattomuutta korostaneelle kyberpuheelle ja internetin paikattomuuden ja sijainnista riippumattomuuden ihanteelle. Paikallinen tekeminen kanavoitui kansalaisverkon kansalaiskeskusteluihin, joissa muokattiin uudenlaista tulkintaa yläkarjalaisuudesta. Paikallisuus ja keskustelijoiden tunnettuus loi turvaa ja lisäsi yhteenkuuluvuutta. Vilkas kansalaiskeskustelu oli juuri sitä aktiivista osallistuvaa kansalaisuutta, jota tietoyhteiskunnan kehittämisessä pyrittiin edistämään. Paikallisuus kiinnitti tietoyhteiskunnan kehittämisen konkreettiseen tekemiseen sekä yhteisöllisyyden ja talkoilla tekemisen henkeen. Paikallinen ja syrjäseudulle sijoittuva menestystarina vei vakuuttavuutta digitaalisen kuilun uhkakuvilta.

Tietoyhteiskunnan kehittämisen yhtenä keskeisenä huolena on ollut digitaalinen kahtiajakautuminen ja kehityksestä syrjään jääminen. Yhdeksi tällaiseksi syrjäytymisvaarassa olevaksi ryhmäksi on tulkittu naiset, joille kohdistettiin omaa tietotekniikkakoulutusta ja tietoyhteiskuntaprojekteja. Syrjäytymisvaarassa olivat myös syrjäseudut. Tietoyhteiskuntakehitykselle ja -kehittämiselle syrjäseudut olivat erityinen haaste, ja syrjäseudun menestystarinalla oli keskeinen rooli tietoyhteiskuntakontekstissa.

Huoli syrjään jäämisestä yhdistää arjen, sukupuolen ja paikallisuuden teemoja, jotka olivat myös pohjoiskarjalaisen tietoyhteiskunnan kehittämisen keskeisiä näkökulmia. Syrjäisyyden ja syrjään jäämisen murtaminen oli kansalliselle tietoyhteiskuntaprojektille keskeistä.

Pohjoiskarjalaisia arjen, sukupuolen ja paikallisuuden tietoyhteiskuntatarinoita ja tulkintoja yhdistää myös se, että ne konkretisoivat tietoyhteiskuntakehittämisen johonkin tunnistettavaan ja tuttuun. Samanaikainen kansanomaisuus sekä julkisuus ja institutionaalisuus ovatkin olennainen piirre kulttuurista tai kansallista yhtenäisyyttä rakentavissa tarinoissa (Kurki 2006). Tietoyhteiskunnasta tuli kansallista yhtenäisyyttä ja suomalaisuutta rakentava kertomus suomalaisista teknologian kehittämisen ja käyttämisen kärkimaana. Strategiat ja julkinen keskustelu loivat tilausta erilaisille tietoyhteiskuntatarinoille. Tietoyhteiskunnasta ja teknologiankehittämisestä tuli tapa kertoa suomalainen identiteetti myönteisessä valossa: teknologiakansana suomalaiset voivat olla ylpeitä suomalaisuudestaan. Tietoyhteiskunnasta muodostui julkinen representaatio suomalaisuudesta, jota aktiivisesti tehtiin osaksi kansallista identiteettiä tietoyhteiskuntakeskustelun sekä -hankkeiden avulla.

Tietoyhteiskunnan kehittäminen koko kansan projektiksi vaati monenlaisia tarinoita. Pelkästään tilastot tai uutiset Suomen asemasta teknologiakehittämisen 


\section{TILATTUJA TARINOITA}

kärkimaana eivät luo kuvaa yhteisestä rintamasta ja yhteisestä projektista. Oppiva YläKarjala -hankkeen tietoyhteiskuntatarinoilla oli kansallista tilausta osana tietoyhteiskuntaa. Ilman tietoyhteiskunnan kansalaisten elettyjä tarinoita ei tietoyhteiskunnasta olisi voinut tulla niin läpäisevää ja kokonaisvaltaista kertomusta. Oppivan Ylä-Karjalan tarinoilla oli tilausta, sillä ne konkretisoivat kansallisen strategian hengen. Tarinat syrjäseutujen asukkaista ja maatalojen emännistä, joista tuli suvereeneja tietoyhteiskunnan kansalaisia ja aktiivisia osallistujia, olivat välttämättömiä tietoyhteiskunnan läpäisevyyden ja koko kansan projektin luomisessa.

Tietoyhteiskunnan julistettiin kuuluvan kaikille, mutta kaikille siitä ei välttämättä muodostunut sellaista kokemuksellista osallisuutta kuin tietoyhteiskuntakehityshankkeiden osallistujille. Yhteinen kokemus syntyi ennen kaikkea hankkeissa ja niiden luomissa tulkintaympäristöissä, joissa tietoyhteiskunnasta rakennettiin kansallista projektia. Yhteinen kokemus ei syntynyt uusista taidoista ja osaamisesta vaan retorisesta maastosta, joka loi edellytykset kuulumiselle ja osallisuudelle.

Tutkimukseni tietoyhteiskuntatarinoilla oli tarkoituksensa, sitoumuksensa ja kontekstinsa. Tietotekniikan ja tietoyhteiskunnan tulkintoja tuotettiin osana tietoyhteiskunnan kehityshankkeita. Tutkimukseni haastateltavat eivät olleet keitä tahansa tietotekniikan käyttäjiä vaan tietoyhteiskuntahankkeiden osallistujia. Tämä sitoumus suuntasi tulkintoja ja tietoyhteiskunnasta kerrottiin hankkeiden määritelmien ja tavoitteiden mukaisesti. Tietoyhteiskunnan tarinoilla oli erilaisia tilauksia: tulkintoja tietoyhteiskunnasta kerrottiin tutkimuksen sekä tutkimushankkeiden tarkoituksiin, osaksi kansallista sekä kansainvälistä tietoyhteiskunnan kehittämistarinaa, median tarkoituksiin sekä hankkeen menestyskertomuksen osana. Tietoyhteiskunnan kertojat ottivat erilaisia rooleja ja positioita erilaisissa konteksteissa: haastateltavat halusivat kertoa jotakin olennaista tietoyhteiskunnan tekemisestä. He kertoivat tilanteisiin sopivia tarinoita, joita heidän oletettiinkin kertovan. Syrjäisillä tietoyhteiskunnan menestystarinoilla oli kansallista tilausta. Yhteiseen kertomukseen tarvittiin erilaisia menestystarinoita, myös syrjäisen ääni ja rajaseudun pioneerit.

Etnografinen tutkimukseni pohjoiskarjalaisesta tietoyhteiskunnasta avaa uusia näkökulmia teknologian kulttuuriseen tutkimukseen, sen kansallisen merkityksen hahmottamiseen sekä teknologian yhä vahvistuvaan rooliin jokapäiväisessä elämässä. Teknologiat ovat tulleet yhä välttämättömämmiksi ja tätä välttämättömyyttä, teknologista imperatiivia, tuovat näkyviin tämänkin työn näkökulmat. Teknologiatarinoiden tilaus on läsnä teknologisessa imperatiivissa, yhä vahvistuvassa kulttuurisessa ja yhteiskunnallisessa paineessa ja välttämättömyydessä hyödyntää teknologioita.

\section{KirjallisuUs}

GRAY, ANN 2003: Research practice for Cultural Studies: Ethnographic Methods and Lived Cultures. London: Sage.

HARAWAY, DONNA 1991: Simians, Cyborgs and Women. The Reinvention of Nature. New York: Routledge. 


\section{SARI TUUVA-HONGiSTO}

HASTRUP, KRISTEN 2004: Getting It Right. Knowledge and Evidence in Anthropology. - Anthropological Theory 4(4): 455-472.

KURKI, TUULIKKI 2006: Neuvostohistorian ja paikallisuuden tulkinnat NeuvostoKarjalan proosassa. - Kulttuurintutkimus 23(2): 39-49.

MACKENZIE, DONALD \& WAJCMAN, JUDY 1985: Introductory Essay: The Social Shaping of Technology. - MacKenzie, Donald \& Wajcman, Judy (eds.), The Social Shaping of Technology. How the Refredgerator Got Its Hum. Milton Keynes: Open Univeristy Press.

MACKAY, HUGH 1997: Consuming Communication Technologies at Home. - Mackay, Hugh (ed.), Consumption and Everyday Life. Culture, Media and Identities. London: Sage.

Tuuva-Hongisto, Sari 2007: Tilattuja tarinoita. Etnografinen tutkimus pobjoiskarjalaisesta tietoybteiskunnasta. Joensuu: Joensuun yliopiston bumanistisia julkaisuja N:0 47.

Filosofian tohtori Sari Tuuva-Hongisto toimii tutkijana Karjalan tutkimuslaitoksella Joensuun yliopistossa. 